An in America

Butrore the Revolution

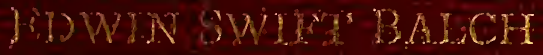







\section{Society of Colonial Wars in the}

Commonwealth of Pennsylvania

\section{Address}

by

Edwin Swift Balch, Esq. 



\section{Art in America}

\section{Before the Revolution}

\section{Address}

before the

Society of Colonial Wars

in the Commonwealth of Pennsylvania

March 12, 1908

by

Edwin Swift Balch, Esq.

Printed by order of the Society

NMAANPG, LIBFARY March, Ig08

Decataloqued
SEP y lyou

SMTHSOWH Wh: WON 
Copyright, I908, by

Edwin Swift BaLCH

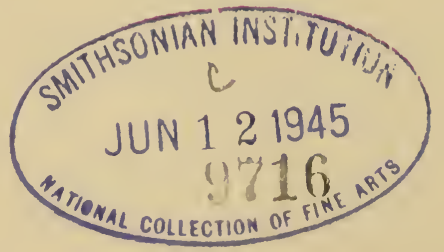




\title{
Art in America Before the Revolution
}

\author{
BY \\ EDwin SwifT Balch
}

Your Excellency: Fellow Members of the Society of Colonial Wars:

Art in America before the Revolution, as a subject for study, divides itself perforce into two divisions. The first is the native indigenous art, the art of the American Indians, or Amerinds, as some ethnologists now call them, which is prehistoric to the landing of the Northmen on the American continent, which still lingers in some places, but which is gradually dying out with its makers. This art extended all over America, from Patagonia to Canada. Except perhaps in Alaska and along the Arctic it is practically one art, the art of the Red men. It varies locally, so that one may say that there are several subdivisions of this art, but it is always sufficiently similar as to make it almost certain that it is the art of one race. It is also sufficiently distinct from the arts of the races of the Old World as to make it almost certain that it is probably mainly an autochthonous art; that is, an art which grew up on the soil and was not imported.

One wave of this art at one period flowed over the plains of the Mississippi and the Ohio rivers, namely the art of the Moundbuilders, among whose mounds some most interesting potteries and sculptures have been found. A later wave, or perhaps merely descent through time, spread 
over the United States the art of our own Indians, an art which extended all over the original American Colonies. Only the other day-in October, I906-a handsomely decorated red pottery vase was found whilst digging the foundations of some skyscraper in New York City, where it is now on exhibition in the American Museum of Natural History.

This art rose to its greatest heights in Peru and Mexico. In Peru it is principally found in the shape of potteries, in many cases admirably sculpted into human heads or human figures, or into animals. Many of these are sculptural; many are caricatural; some, showing the effects of disease, are pathological. These Peruvian heads, curiously enough, often resemble European heads, and one might ascribe them to Spanish influence had not such quantities been dug up in prehistoric graves. In Mexico, besides potteries, there are some pictures and many stone sculptures. Some of the heads are grandly done and resemble Egyptian heads. Much of the Mexican art, unfortunately, is loathsome and hideous. The motives are snakes and death's heads. It is not art which has evolved in these carvings, but an attempt to bring out in stone some ghastly superstitions which must have been rampant through Central America. There is some evidence that the death's heads were related to cannibalism. At any rate, a study of their art has made me feel that Cortez did a rather good work when he wiped out old Mexican civilization, and that it is useless to waste sympathy on such a gang of toughs as Montezuma and the Aztec priests. I consider some phases of Mexican art as the lowest and most degraded ever reached by any art.

Along the Arctic we find the art of the Eskimo, a race probably allied to the North Asiatics; and along the shores of Alaska, we find an art which, while it has some Mexican traits, showing some cousinship to Mexican art, yet in the 
main is related closely to the art of the Brown races, the Polynesians and the Australasians generally; to the art of New Zealand, of Rapa Nui, of Papua, and of Hawaii.

The second division of my subject is the art of the intrusive white races of Europe, which its makers brought with them across the Atlantic into the New World. This is the art of Colonial times, which cannot be termed correctly Colonial art, because it is really nothing but transplanted European art.

The art of Colonial times is a purely intrusive art, an art which was full-fledged before reaching American shores. It was brought over by the European immigrants, and if we turn over the pages of history we find that there were three main streams of European immigration into America: a French stream into Canada; an English and Dutch stream into the United States; a Spanish and Portuguese stream into Central and South America. If, then, we look at the arts of these nations in the seventeenth and eighteenth centuries, we find the immediate parents of the art of America in Colonial times.

I do not share the view, held by some ethnologists, that religious beliefs have anything to do with the underlying motives of an artist. It is the esthetic sense, which all men have in a greater or lesser degree, which makes some men want to paint or sculpt. Some men like to imitate, to try to reproduce men or animals or landscapes, because these appeal to what we may call their esthetic faculties.

But as it is necessary for most artists to live by their work, the demand for certain forms of art is pretty certain to regulate the output. And as the ruling church in France and in Spain not only admitted paintings and sculptures to its buildings, but paid to have them, it is only natural that many artists in those countries made their living by painting and sculpting crucifixions and madonnas and saints. This was done even more in Spain than in France, and though 
we find some fine portraiture in Spain, with Velasquez as the great master, there was done for churches and convents still more painting, whose best known Spanish makers are Murillo, Ribera and Zurbaran.

As a necessary corollary to this, the art that came into Spanish Mexico was this same church art, which descended immediately from such painters as Murillo, Ribera and Zurbaran. And in the churches of Mexico to-day there are many such pictures which either were brought over from the Old World, or were painted in Mexico by painters following these already conventionalized traditional subjects.

The same is true of old French Canada, only in a lesser degree. There are still in Quebec some few church pictures which certainly antedate the Revolution, but I cannot say whether these were painted on American soil.

In Holland and in England the situation of the artist was quite different from what it was in Spain or in France. Not only did the ruling churches not pay for pictures and sculptures, but they did not tolerate them in their buildings, and in some cases the zeal of their adherents went so far that, if I am not mistaken, they smashed the works of art that had come down to them from earlier times. The artists therefore naturally worked in other directions, in the lines of least resistance and most profit, and in the seventeenth century we find a great art in full bloom in Holland, with Rembrandt, Franz Hals and Van der Helst in portraiture; Paul Potter and Cuyp in animal pictures; Pieter de Hooghe, Jan Steen and Metzu in genre; and Hobbema and Ruysdael in landscape, among its leading exponents. This Dutch art must have been well supported or it would never have reached the output, both in quality and quantity, which makes it one of the great art epochs of all time.

It is a curious fact, nevertheless, that the greatest painter, perhaps, of religious subjects was a Dutchman, Rembrandt. In his "Supper at Emmaus," "The Holy 
Family," the etching of "The Hundred Guilder Plate," and "The Presentation in the Temple," for instance, possibly because these pictures were not "potboilers," there is a technical mastery and a depth of feeling probably unattained by any Italian or Spanish painters in religious subjects, and in this line, as well as in all groups of figures or in portraits, Rembrandt stands easily at the top.

In England art advanced much less rapidly than in Holland. Doubtless this was due partly to England's insularity, partly to a certain inaptitude of the English race for art, and partly to the then still strongly developed system, which among the Hindus is called the caste system, and which two centuries ago prevailed sufficiently in England for royalty and the nobility to be practically the only important patrons of art. Landscape did not grow up in England until the latter half of the eighteenth century, when Wilson became its first, but now almost forgotten, master. Royalty and aristocracy, however, probably considered that they were good-looking and were willing to pay, in some cases cash, to see their features on canvas, and the result was that in the sixteenth, seventeenth and eighteenth centuries there were some good portrait painters in England, almost all foreigners, among whom may be mentioned Holbein, Clouet, Antonio Moro, Sir Godfrey Kneller, Vandyke, Sir Peter Lely, Raeburn, Sir Joshua Reynolds and Gainsborough. The names of the painters working in Holland and in England in the sixteenth, seventeenth and eighteenth centuries give the clue to their descendants in the American Colonies in the eighteenth, and these naturally turned to portraiture and historic incident, although, unfortunately, they were much weaker in all respects than their great predecessors.

The art of portrait painting, as we understand the term, is practically the art of placing on a flat surface in colors an imitative reproduction of the sitter in order to 
convey to the onlooker a likeness of the sitter. As far as I know, our imitative portrait painting is confined to the White races, and even among them it is a late form of art. I am not aware that it existed among the Kaldeans, the Assyrians, or the Egyptians, and the first portraits in our style extant I have seen are the Greek heads, of about 200 B. C., which have been dug up in the Fayum, Egypt. These are really the beginnings of European portraiture, and it is probably fairly accurate to say that the ultimate direct fountain-head of the art of American Colonial times is the Greek art of the Fayum.

There was almost no art among the Colonials of the seventeenth century. This is perhaps not to be wondered at, when we look at their environment. It was a struggle for life. People had to plant corn, and cut trees, and hunt for food, not think of works of art. It would not have been pleasant posing for one's portrait when the sitting might be interrupted suddenly by a Red man sneaking up behind the back fence and shooting a stone-headed arrow into the sitter's ribs. Still, it is almost certain that there was some painting in the Colonies by Dutchmen in the seventeenth century. Henry Darrach, Esq., of the Philadelphia Bar, informs me that he has seen some old records stating that some portraits of Indians were painted by Dutchmen in their settlements on the Delaware, and this must have been some time between I623 and I664. He has also seen some old engravings or drawings of Indians which must date far back and are probably the work of Dutchmen. There is every probability that the Dutch did do some painting at this early time, since it coincides with the best period of the art of Holland. The following quotation also shows that there was a little portrait drawing in the Colonies before I 700: “Cotton Mather, in his 'Magnolia,' speaking of the aversion of John Wilson to sit for his portrait, says 'Secretary Rawson introduced the limner'-showing there 
were limners in Boston in 1667."* Another clue to an early artist in the Colonies is found in the following sentence: "There is a surmise that one Tom Child, who died in Boston in 1706 , was a still earlier limner of features." $\dagger$ In the eighteenth century conditions had become rather more settled and portrait painters, whose names have come down to us, begin to appear. I have traced so far, either from their own works or in books, the names of some forty painters who were in America in Colonial times: John Watson, Peter Cooper, Peter Pelham, John Smybert, Robert Feke, Matthew Pratt, Williams, Nathaniel Smybert, Jonathan B. Blackburn, Green, Theus, John Meng, J. Claypoole, Woolaston, L. Kilbrunn, Taylor, Gustavus Hesselius, Cain, Frazier, Abraham Delanoy, Patience Wright, Winstanley, Henry Bembridge, Cosmo Alexander, James Peale, Ramage, Field, Trenchard, Manly, Durand, Smith, T. Earle, Campbell, T. Coram, Thomas Spence Duché, Joseph Wright, Charles Wilson Peale, Benjamin West, John Singleton Copley, Charles Gilbert Stuart and John Trumbull.t

Certain men are also occasionally mentioned as early American painters. Among these are William Williams, Mather (or Matthew) Brown, Robert Fulton, William

\section{*Tuckerman.}

†The Memorial History of Boston, I88I, Vol. IV, p. 382.

$\ddagger I$ wish to state that I consider this paper as an only approximately correct sketch of the art of Colonial times and that it is neither exhaustive nor scientifically accurate in regard to the artists of Colonial times. Original records are practically inaccessible to me, and I have had to depend for historical and biographical data about the painters on secondary authorities, whose statements I am unable to verify. Among these authorities are: William Dunlap, History of the Rise and Progress of the Arts of Design in the United States, New York, 1834; Henry T. Tuckerman, Book of Artists, American Artist Life, 1867; S. G. W. Benjamin, Early American Art, Harper's New Monthly Magazine, Vol. LIX, I879; Henry Simpson, The Lives of Eminent Philadelphians, I859; J. Thomas Scharf and Thompson Westcott, History of Philadelphia, I884, Vol. II; John D. Champlin and Charles C. Perkins, Cyclopedia of Painters and Painting; Charles H. Caffin, The Story of American Painting, New York, Igo7.

$\mathrm{I}$ am indebted also for much valuable information to $\mathrm{Mr}$. Ernest Spofford, Assistant Librarian of the Historical Society of Pennsylvania. The criticisms of the art are my own. 
Dunlap, Colonel Henry Sargent, Edward Savage, Robert Edge Pine, Polke, Malbone, Sharpless, Wertmïller, St. Memin, Martin, Güllagher, Robertson, Samuel King, Belzoni, Roberts and Malcolm. Some of these men may have painted before the Declaration of Independence, but in the main they are post-Revolutionary painters.

John Watson was a Scotchman. He was born in 1685 , and came to the Colonies in I 715 . He painted portraits in Philadelphia and Perth Amboy, New Jersey. He died on August 22, I768. Two little half lengths, now in the Historical Society of Pennsylvania, have been ascribed to him by one or two writers. One, done in India ink wash, represents a man in a suit of armor, and is inscribed as a portrait of Governor Keith. The other is a lead-pencil sketch of a lady in a very al fresco costume with a shepherd's crook, and is inscribed "Lady Keith." That these drawings are by Watson is uncertain; but personally I doubt whether they are by the same man.

Peter Cooper was one of the earliest painters of Colonial times, and curiously enough he painted landscapes. Of the man himself I know nothing, except that a note in the Library Company of Philadelphia says: "It appears by the Minutes of the Common Council, May 27, I7I7, that Peter Cooper was admitted a freeman of Philadelphia on payment of $5 / 6$." $\mathrm{He}$ was perhaps the first landscape painter of Colonial America. For at the entrance of the Library Company is a picture of his, presented by the Hon. George M. Dallas, Minister to England. In a letter dated "London, January I2, I857," Mr. Dallas says that a member of Parliament found this picture in a London curiosity shop and gave it to him, and that it was believed in London to have been painted in 1720 ; he also calls it "an antique daub." On a sort of shield, the picture is inscribed as "The South East Prospect of the City of Philadelphia, by Peter Cooper, painter." Many of the houses are numbered, and 
these numbers correspond with a list, on another shield, of the house-owners, among which are the names of my own ancestors, Edward Shippen and Joseph Shippen. I do not agree with Mr. Dallas, in calling this work a daub. Of course, it has no esthetic qualities, the drawing is hard and tight, and it lacks most of the qualities of landscape painting. Nevertheless it has some color; there is some drawing; the artist saw that buildings in light and buildings in shadow varied in value and in color. Altogether I should say it was rather a primitif picture-one suggesting the method of the Italian pre-Raphaelites-than a daub. Its value as art may be small, but if it is really the earliest remaining landscape of Colonial times in existence, this neglected oil painting ought to be worth, frame included, ten times its weight in gold.

In the same year as Peter Cooper, I7 I7, "Peter Luolie, Aaron Huliot and Samuel Johnson, all painters, were also admitted" as freemen of the City of Philadelphia. Whether they were more than house-painters or sign-painters does not seem, however, to be known.

Peter Pelham was born in London. $\mathrm{He}$ is said to have arrived in America in I7I7. He settled in Boston in I724, and opened there in I734 a school in which painting was taught as a branch of education. This was probably the first art school in America. He died in Boston, December, I75I.

John Smybert, or Smibert, was a Scotchman. He was born in Edinburgh in I684, studied in London and Italy, and came over to Newport with Bishop Berkeley in January, I729. He soon went to Boston and painted portraits there until his death in $\mathrm{I} 75 \mathrm{I}$. His best known picture is the portrait group of Bishop Berkeley and his family, now the property of Yale University.

Robert Feke, of Quaker descent, was born, probably, on Long Island. On some voyage he made he was captured 
at sea and taken as a prisoner to Spain, where he is believed to have obtained some notions of painting. He settled in Newport, where there are still a few of his portraits. He also painted in New York and in 1746 in Philadelphia. He died at Bermuda in the latter half of the eighteenth century, aged about forty-four.

Matthew Pratt was born in Philadelphia in 1734 , and died there in 1805 . He was a pupil of Benjamin West in London in I764-I768. He lived mostly in Philadelphia, and for many years painted signs and house decorations there before turning to portraiture. These signs appear to have been more highly thought of than his portraits, and judging from what has been said of them they were probably more artistic. Two of his canvases, portraits of Benjamin Wesst and of Mrs. Benjamin West, are now in the Pennsylvania Academy of Fine Arts. His most ambitious effort, known as "The American School," is now in the Metropolitan Museum of Art, New York, and represents the painting room of Benjamin West in London. Matthew Pratt's pictures are simply tyro's work and need no special comment.

Williams was an Englishman who, it is believed, was the first teacher of Benjamin West. He painted some portraits in Philadelphia about I746-47.

Nathaniel Smybert, son of John Smybert, was born in Boston, January 20, I 734, and died there November 8, 1756. He started at portrait painting and gave great promise.

Jonathan B. Blackburn was born in Connecticut about I700. Another account says he came over to the Colonies from England. He painted portraits in Boston from $175^{\circ}$ to 1765 .

Green arrived in the Colonies about 1750 , and painted portraits from then until towards 1785 .

Theus painted portraits in South Carolina from about 1750 to 1785 . Miss Marguerite Ravenel, of Charleston, 
informs me that some of his portraits have been attributed to Copley.

John Meng was born in Germantown on February 6, I734, and died about I754. He is said to have painted some portraits. There are several in the Historical Society of Pennsylvania which may be by him.

James Claypoole may have painted portraits in Philadelphia about 1756 .

Wollaston, or Woolaston, was probably a British subject, who paid a visit to the American Colonies. He painted portraits in Philadelphia in I758, and in Maryland in I 759. $\mathrm{He}$ also painted portraits in Virginia and Maryland about 1772. Among these was one of Mrs. Washington.

L. Kilbrunn was probably an Englishman. He painted portraits in New York from about I76I to I772.

Taylor painted miniatures in the Colonies about 1760.

Gustavus Hesselius, probably a Swede, although one authority calls him an Englishman, was painting portraits in $176_{3}$ at Annapolis, Maryland, where he was the first teacher of Charles Wilson Peale. There are two portraits by him in the Historical Society of Philadelphia, of an ugly gray color, and wooden in drawing.

Cain painted portraits in Maryland about 1760.

Frazier was painting at Norfolk, Virginia, about 1763.

Abraham Delanoy was born about I740 and died about I786. He was a pupil of Benjamin West and painted portraits from about I 760 until his decease.

Patience Wright was born in 1725 , and died in 1785 . She was of Quaker descent and resided in Colonial times at Bordentown, New Jersey. She used to model heads and figures, principally in wax, which are said to show some imitative talent. She started her son, Joseph Wright, at painting, and is probably the earliest woman artist in the United States. 
Wistanley, or Winstanley, painted portraits in the Colonies about I 769 .

Henry Bembridge, of Philadelphia, painted portraits about 1770-1800. He studied in Europe under Mengs and Battoni, and had enjoyed a liberal education. There are some portraits of his in Charleston.

Cosmo Alexander, a Scotchman, came over to the Colonies from England about the year I770. He resided, for awhile at least, at Newport, where he was the first teacher of Gilbert Stuart. He died in Scotland between I 772 and I775.

James Peale was an early painter of miniatures, about I 770 .

Ramage was an early miniature painter. $\mathrm{He}$ was an Irish gentleman, and painted many small portraits in Boston about I77I, and afterwards.

Field painted portraits about 1770 .

Trenchard perhaps painted portraits as early as 1770 .

Manly painted portraits in Virginia about $I 772$.

Durand painted a number of portraits in Virginia about I 772 .

Smith was a portrait painter, probably of late Colonial times. He was a native of Long Island, and, it is believed, was one of the first Americans to study painting in Italy.

T. Earle possibly painted portraits in Connecticut in 1775. He afterwards studied with Benjamin West, and between I 786-I792 painted portraits in Connecticut, New York and Charleston. He also drew some historical scenes, possibly the earliest attempts of the kind in America. Some of these were engraved by a comrade-at-arms of his, Doolittle.

Campbell painted portraits in late Colonial times.

Coram painted portraits in Charleston about $\mathrm{I} 78 \mathrm{o}$, and possibly did so before 1776 . 
Thomas Spence Duché may have painted portraits in the Colonies immediately before the Revolution. He certainly did so shortly afterwards. An example of his work, in the Historical Society of Pennsylvania, shows that his color was rather more mellow than that of most of his fellow craftsmen. In some cases, however, the poor cold color which has come down to us in many pictures of Colonial times is undoubtedly due to the cochineal lakes and the bright, probably lead, yellows fading out or blackening.

Joseph Wright was born at Bordentown, New Jersey, in 1756 , and died in Philadelphia in 1793 . He was a pupil of Benjamin West and had also been to Paris. Among other portraits, he painted one of General Washington and one of Mrs. Washington. He was a designer and die-sinker at the United States Mint at Philadelphia, and he probably designed some of the earliest coins and medals struck in America.

F. V. Doornick and O. A. Bullard are mentioned as two painters of Colonial times.

There are several engravers of Colonial times. Nathaniel Hurd, about I764, was one of the earliest. Paul Revere, about I766; Amos Doolittle, about I 77 I ; Smithers, about I773; Jennings, about I774; and Henry Dawkins, about $\mathrm{I} 774$, all did some engraving, most probably on copper plates. Edward Duffield also designed and executed several medals about 1756 .

A rather odd phase of portraiture in Colonial times are the silhouettes, generally cut out of black paper, by which some of our ancestors have sent down their features to posterity. Dr. S. Weir Mitchell tells me that the Friends, while objecting to ordinary portraits, did not object to silhouettes, and this was probably one reason for their vogue. How accurate they are as likenesses is hard to determine, but they were done with the help of a sort of measuring machine. There are several from Revolutionary times in 
the Library Company of Philadelphia, which are interesting because they were done by Major André.

Five of the painters of Colonial times are much superior to the others. These are John Singleton Copley, Benjamin West, Charles Wilson Peale, Charles Gilbert Stuart and John Trumbull.

John Singleton Copley was born in Boston, July 3, I737, and died in London, September 9, 1815. He was a pupil of Peter Pelham, his stepfather. He painted in America until I774, when he went to Rome, and in 1775 he went to London. He painted portraits and historic incidents. Some of his portraits are fair in proportions and in color, but often the figures are stiff, with hard outlines. To use studio language, his drawing is rather tight. He made other mistakes. For instance, in his portrait group of $\mathrm{Mr}$. and Mrs. Izzard, painted at Rome, and now in the Boston Museum of Fine Arts, the figures are fairly well drawn and painted, but the landscape background in which the Colosseum looms up in the distance is lighted as would be a tapestry, not an open window. It was, of course, the style of the times, but nevertheless such older painters as Pieter de Hooghe or Antonio Moro would not have been guilty of such a blunder. Copley seems to me to have been a less artistic handler of paint than West or Stuart, but a better draughtsman than either. In some of his historic pictures also, such as the "Death of Major Pierson," now in the Boston Museum of Fine Arts, Copley rises to a higher level than West as a painter of subject pictures. They are successful illustrations, something one could not say, for instance, of West's "Death on the Pale Horse."

Benjamin West was born at Springfield, Pennsylvania, October I0, I738, of a Quaker family, and died in London, March II, I820. He started painting portraits in Philadelphia, then moved to New York. In I 760 he went to Italy and in 1763 to London, where he resided most of his life, 
and where he became president of the Royal Academy after Sir Joshua Reynolds. West sometimes painted great compositions, of which "Death on the Pale Horse," now in the Pennsylvania Academy of the Fine Arts, is perhaps the most widely known, and it may be said that these compositions are singularly unsuccessful. They are made-up attempts to limn something which the artist never saw and never felt"grandes machines," a Frenchman would call them; and they entirely lack any quality of beauty and any power of imparting artistic emotion. Some of West's portraits, however, are very different from his big failures. They show fair drawing, fair proportions, fair light and shade, a pleasant subdued color, and the outline is lost and found. Two of his best portraits are of kinswomen of mine own-one of Mrs. Joseph Shippen, and one of Mrs. Admiral Digby as a little girl. On the whole I should say that Benjamin West painted the best portraits which have come down to us from pre-Revolutionary times. Nevertheless, as he spent his life in England, he must be considered rather as an English than an American painter.

Charles Wilson Peale was born in Chesterton, Maryland, on April I6, I74I, and died in Philadelphia, February 22, 1827. During the Revolution he served in the army and commanded a company at the battles of Trenton and Germantown. He was a versatile man. He worked in leather, wood and metal, and made harnesses, clocks and silver ornaments; also false teeth, notably General Washington's, out of walrus tusks. He started a museum of scientific specimens, and helped in forming a school of fine arts, which eventually became the Pennsylvania Academy of the Fine Arts. He studied painting under Gustavus Hesselius at Annapolis, Copley at Boston, and in I770-I774 under Benjamin West at London. He painted portraits principally in Maryland and Philadelphia. A number of these are now in the Pennsylvania Academy of Fine Arts: 
Francis Scott Key; Robert Morris; the artist himself; the artist in his museum; and George Clymer. In many cases the historic importance of his sitters makes his work very valuable. His work is tolerably good in most technical qualities, such as drawing, proportions and light and shade. The handling of the paint is dull, yet I should imagine that his portraits are fair likenesses, which show something of the characteristics of the sitters. He is distinctly one of the best artists of Colonial times.

Charles Gilbert Stuart was born at Narragansett, Rhode Island, on December 3, I755, and died in Boston, July 27, 1828 . He went to Scotland in 1772 with his teacher, Cosmo Alexander. In I775 he became an assistant to Benjamin West. In $\mathrm{I} 785$ he set up a studio of his own in London. In $\mathrm{I} 792$ he returned to America. He spent most of his time after that in Boston. Among his works are portraits of Washington, Mrs. Washington, John Adams, Jefferson, Robert Morris, Thomas Willing, William Bingham, Alexander J. Dallas, Paul Revere, Monroe, Stephen Decatur, Chief Justice Shippen, Horace Binney, Benjamin West, and many other prominent persons. I am inclined to think that Stuart is usually overrated as a portrait painter. Too often the fundamentals are neglected in his work. He seems to have made it a practice of concentrating all his knowledge on the head and doing the rest of the picture carelessly. He not infrequently placed his heads too low on the canvas. Often his portraits have impossibly lowdown shoulders, little short arms and dwarfed torsos, the body, that is, being much too small in relation to the head. Whether Stuart did this on purpose or not must remain uncertain, but it is bad drawing, and therefore poor work. Just as in the case of many other portrait painters, however, the blame for his errors doubtless rests largely with the sitters. Some of them surely would not give Stuart sufficient sittings; sitters sometimes think three or four sit- 
tings should be enough, although good portraits sometimes require fifty or more. Then again they probably wanted to be made what they considered good-looking and Stuart wanted the cash, and so the matter was adjusted by a pretty but inaccurate picture. Painters must keep the pot boiling. You know, doubtless, of the one to whom a young lady sitter said: "I know I have a large mouth, but I want you to make it small." "Oh," said the painter, "if you prefer, I will leave it out altogether." Some of Stuart's work, however, is much above his potboiling level. The handling of his paint, his coup de pinceau, is always good. Some of his heads are simply splendid and are probably the best by any American painter. Some of his figures, also, have good drawing, proportions and color. Such a one, for instance, is the portrait of.Dr. Fothergill in the Pennsylvania Academy of Fine Arts. Among his other good works may be mentioned the two portraits, of the first Spanish Minister to the United States, Señor de Jaudenes y Nebot, and of his wife, recently placed in the Metropolitan Museum of Art in New York. These show Stuart at his best. They are admirably drawn, and are signed all over the canvas with Stuart's peculiarities in color and handling, and if all his works were as good, I should place him in the front rank of portrait painters.*

John Trumbull was born at Lebanon, Connecticut, June 6, I756, and died in New York, November Io, I843. Trumbull served in the War of Independence as aide-decamp to Washington, and as Deputy Adjutant-General under Gates. He painted portraits and historic pieces. In

*Charles C. Binney, Esq., of the Philadelphia Bar, after the reading of my paper, called my attention to the following statement by his grandfather, Mr. Horace Binney, about his portrait by Stuart: "Stuart." said Mr. Binney, "had all forms in his mind, and he painted hands and other details from an image in his thoughts, not requiring an original model before him. There was no sitting for that big lawbook that, in the picture, I am holding. The coat was entirely of Stuart's device. I never wore one of that color (a near approach to a claret color). He thought it would suit the complexion." George C. Mason: The Life and Works of Gilbert Stuart, I879, p. I4I. 
I780 he went to London to study under West, but was imprisoned for eight months, and returned to America in I782. After the peace he went again to England. He painted the Battle of Bunker Hill, the Surrender of Burgoyne, the Surrender of Cornwallis, the Resignation of Washington at Annapolis, the Battle of Princeton, the Battle of Trenton, portraits of Washington, Hamilton, Rufus King, and many other pictures. John Trumbull was a fair draughtsman and a fair colorist, and some of his portraiture is rather nicely handled. His historic pictures, while they are clever compositions, seem to me to be deficient in the most important element of art; they lack beauty and therefore do not produce emotion. They are really illustrations; very good illustrations of historic incidents, but quite as suitable for the illumination of the page of a book as to be broadly displayed on a wall.

I once heard a Frenchman, a Paris connoisseur and dealer in pictures, say of Stuart: "Il appartenait à l'école Anglaise." I think this observation is perfectly accurate. But I am inclined to go further and to say that I think that all the painting of Colonial times belonged to the so-called English school of portraiture, which school, however, practically consisted of foreigners who had come to England from the continent. The painters of Colonial times did not form an American school at all: American individuality did not begin to assert itself in painting before 1825 , and the painters of Colonial times and of Revolutionary times are really nothing but a reflex of those living in the mother country.

None of the painters of Colonial times proper can rank among the great portrait painters. It is impossible to really classify painters, but it may be hinted at roughly, and referring to portraiture only, Rembrandt and Velasquez may be safely placed at the front. Then come a number of great portraitists, not all perhaps equally excellent, but all distinctly great in one or more portraits. One might mention 
among these, perhaps, Titian, Holbein, Hals, Van der Helst, Leonardo, Hogarth, and some others. And among these men the best Colonial portrait painter cannot be included. Gilbert Stuart in his best work, perhaps, may be ranked among first-rate portraitists, but he is really rather postRevolutionary than Colonial.

Of sculpture in Colonial times there is little to say, in fact, sculpture was a practically unknown art in the Colonies. About the only genuine pre-Revolutionary sculpture I have seen is one you doubtless all also have seen: "Le Chien D'or," the "Golden Dog," at Quebec. Even this may have been carved in Europe, but I believe the artist is unknown. It dates from somewhere around 1750 . It is a fairly good high-relief carving, but unfortunately much weathered away by exposure. Under it are carved the well known lines:

$$
\begin{aligned}
& \text { "Je suis un chien qui ronge l'os, } \\
& \text { En le rongeant je prends mon repos, } \\
& \text { Un temps viendra qui n'est point venu, } \\
& \text { Ou je mordrai qui m'aura mordu." }
\end{aligned}
$$

"Le Chien D'or" was put up as a threat and it hung over the doorway of its original owner's house until the latter was torn down and replaced by the Quebec post office. Now the "Golden Dog" is over one of the doorways of the post office, in the spot where it has always breathed vengeance. The artistic style of the bas-relief is distinctly French Renaissance; thẹre is nothing whatever English about it. It reminds one artistically of the Salamander of François I.

Still, there is one sculptor who doubtless began in Colonial times, although he must be looked on as a postRevolutionary artist. This is William Rush, probably the first American sculptor, to whom my attention was called by Mr. W. Bleddyn Powell. William Rush was born in Philadelphia on July 4, I756, and died there on January 27 , I833. He served in Washington's army and several times in the Philadelphia City Councils. He carved many statues, making almost a specialty of the figureheads of ships. 
There is another art of which I wish to say a few words, as an example of how some of our American arts and industries can be traced back to some distant corner of the globe. This is the art of tile making, which is now being revived at Doylestown. It came to Pennsylvania before the Revolution, brought over by Pennsylvania Dutch, although it did not take much hold at the time. It is claimed by some persons that the Dutch got their taste for tiles from the Chinese, with whom they were trading already in the seventeenth century. It seems to me, however, more likely that the Dutch got this art from the Spaniards in the times when Charles the Fifth was their ruling sovereign; the Spaniards learnt to make tiles from the Moors of Southern Spain; the Moors brought the art with them from Egypt and Arabia in their conquest of North Africa. But they had received it themselves at least partly from Assyria and Persia, where the Palace of Darius at Sousa of 404 B. C. had numerous friezes made of colored tiles, and tile-making undoubtedly goes back to Kaldea and early Egypt, from which it probably gradually descended to Pennsylvania.

Taking Colonial times as a whole, one cannot speak of them as an epoch when there was anything like a great art. Nor can one rank any artist of Colonial times as more than about third-rate among the artists of the world. Nevertheless some of these men emphatically did well. They had no training; there were no real academies where anyone could learn the basis of all painting, how to draw; they had no artistic environment, no old masters nor galleries to refer to, no fellow-painters to sharpen their wits against; their patrons, on whom they depended for a living, probably knew and cared mighty little about art for art's sake. I think it is a remarkable fact, not that these men painted no better than they did, but that they painted as well as they did. And I think that the Society of Colonial Wars is true to its mission in trying to do something to keep their memory green. 
Post Scriptum. Christopher Witt is believed to have painted in I704 a portrait of Johannes Kelpius, "the hermit of the Wissahickon," which is now in the Historical Society of Pennsylvania. My attention was called to this painting by Julius F. Sachse, Esq., who also informs me that Henry Dawkins engraved on copper plates, in Pennsylvania, as early as 1759 . 

List of papers, forming Volume I, published by the Society of Colonial Wars in the Commonwealth of Pennsylvania :

I. The Right Reverend Cortlandt Whitehead, S.T.D.: "The Capture of Fort Duquesne."

2. Dr. Edward Shippen, U. S. N.: "Memoir lof Henry Bouquet."

3. Frederick Prime, EsQ.: "Dedication of Tablet in the State House, Philadelphia."

4. Dr. Persifor Frazer: "Some Wars in Science."

5. George Cuthbert Gillespie, Eso.: "Early Fire Protection, Fire Insurance Companies and the Use of Fire Marks."

6. Francis Howard Williams, Eso.: "American Literature in the Colonial Period."

7. George Champlin Mason, Esq.: "Environment the Basis of Colonial Architecture." 

• 

